\title{
Unified educational space of the CIS countries in conditions of integration and information
}

\author{
Tatiana Shaposhnikova ${ }^{1, *}$, and Marina Yakushkina ${ }^{2}$ \\ ${ }^{1}$ ISED RAE, Comparative Education Center, Moscow, Russia \\ 2 IME RAE, Moscow, Russia
}

\begin{abstract}
The article deals with the issues of integration as the most important characteristics of the modern globalized world, the formation of the world educational space and its most important characteristics. The authors have focused on understanding and analysis of the CIS countries educational relationships, the possibility of the formation of the Commonwealth educational space as a result of the integration process, its unity and integrity. According to the authors, informatization advocates an important factor that contributes to this interaction.
\end{abstract}

The concepts of "global education", "common educational space", "information age", "informatization" are characteristics of modern scientific educational research. These terms indicate that the integration processes in education exist, and there is an interaction between all actors of the educational activities and education space (social institutions, educational institutions, people within certain territorial boundaries or other unifying framework).

Formation of a unified space in almost all spheres of life - political, economic, socio-cultural, educational - is the result of the integration process, which is characteristic of the current stage of development of world civilization. The word "integration" (Latin) means "reunion". Integration - the process of creating a new multi-part, a larger constant, unit, community. It has the appearance of a new holistic, common association. It begins to exist and to operate independently from a certain point. Combining the efforts of several regions, countries may be an example of such cooperation from the political point of view. The purpose may be the organization of their cooperation in various spheres of life, and the result is the emergence of an independent neoplasm, having the features of the whole, common and integral. The emergence of new integrative qualities of those interacting and cooperating with each other is regarded as the end result of the integration. The emerging new integrity can be arranged either by territorial principle in the frame of certain territorial bounds or, for instance, like a supranational formation, where the subjects of integration are united by the common culture, spiritual values, traditions and rules, but not by the unity of the territory.

Scientists from different fields of scientific knowledge actively use the term "integration". American economist Fritz Machlup, who carried out a retrospective analysis of the concept, found that this concept appeared after 1942, the phenomenon, of course, appeared much earlier. For the first time, the term began to be used in international economic relations. More narrow definitions of this concept, for example, the term "political integration", "educational integration", "cultural integration" and others were introduced in scientific terminology from the beginning of the 50 s of the last century $[1,15]$.

The Merriam-Webster English Dictionary provides the definition of "integration" concept. There integration is defined as an action or process by which the various groups (or races) are united together on an equal basis into a unified company or organization. Accordingly, "to integrate" means to form, to attach or to combine into a unified whole. The dictionary describes the word "unite" as a synonym, which means to come together to form a coherent whole [2].

The famous comparativist Giovanni Sartori believes that the integration can be represented as a finite state or process, or function that relevant agents (countries, states, parties, groups, etc.) carry out. This scientist points out that according to Western analysts the concept of "integration" does not mean any kind of "connection" or any kind of "merging". For example, American scientists tend to deny the fact that integration has anything to do with the "forced uniformity." According to them, the possibility of integration can only be due to the pluralistic character of the social system, and it also serves as a necessary condition for its development [3, $67]$.

Let us turn to the attempts to identify its most important characteristics, using the example of political integration. In the Anglo-American "Dictionary of Political Analysis" Jack Pieno, Robert Riggs and Helena Robin the explanation of "integration" includes the concept of "process" by which two or more political units strengthen contacts with each other by mutual

Corresponding author: tatianashap@,inbox.ru

(C) The Authors, published by EDP Sciences. This is an open access article distributed under the terms of the Creative Commons Attribution License 4.0 (http://creativecommons.org/licenses/by/4.0/). 
cooperation. As a desirable or logical result of an interactive process, for example, political, a political union is often considered. Political integration requires formal or informal institutions for co-decision [4].

The problem of educational space boundaries is important for representatives of new integration concepts (B. Anderson, M.Bison, E.Harell, T.Dzh.Pempel, E. Frost). Should the educational environment have clearly defined boundaries: geographic, ethnic, linguistic, etc.? Perhaps the boundaries should be defined by the concentration of the most intensive contacts - economic, political, social, educational $[5 ; 6]$.

Some scientists prefer to interpret the concept of a common space as geographical characteristics and those that can be attributed to the social and cultural characteristics, the so-called identity. For example, according to E.Harella, it can be considered as presuppositions of integration: (1) the perception of the region (perceived region) and (2) shared by its residents identity (shared identity) [7]. The first characteristic refers to the geographical boundaries, the second - to the formed regional identity of inhabitants, which allows to separate them from living in other regions. However, many researchers have noted concerns about the stability of the union only on the basis of "identityconsciousness" when the so-called "regional identity" (ethnic, cultural, linguistic) is not supported by intense economic, political and social contacts [8].

An idea about the integration with several positions: as a process, as a result, and as the process leading to a specific end result is the optimal in the era of globalization. This position explains the differences in the understanding and explanation of the concept of different scientists and allocated contradiction. It is inherent to the content of the concept and it is in a sense of the cause of the development of this concept. In the context of globalization based on the characteristics of "integration" and the main contradiction in its development the integration is understood as the process which has two elements - unifying and divisive. Globalization contributes to a strengthening of the relationships and interdependencies between the actors of integration and their division [9]. Researchers in the field of educational space note that "core" common to all systems is allocated within the world of education. The core has the form of a supranational education, dictating national education systems development trends. They are required for them to be competitive on the world market of educational services. On the other hand, the processes are marked, indicating active desire of educational systems to retain their national characteristics and peculiarities [10].

Today, education advocates, along with other areas of life, the most important actor of integration, effective way to communicate cultures, regions, countries, ethnic groups and civilizations. Integration processes in the formation, the result of which - the emergence of a world educational space, and further development of the national peculiarities of the education systems of different countries are considered in the framework of a common methodology of social cognition. At its core, the integration in the common educational space is a manifestation and display of real connections, represented objectively in education as one of the social institutions of society. It is important to note that the integration into a common educational space, according to experts, is not an easy assimilation (and/or absorption of the weak by strong community in the process), but mutually voluntary movement towards wholeness. This stimulates the development of the best characteristics of integrable subjects and creates the core of these supranational education. As a result, it provides the appearance of a new quality, characteristic of large integrated system for all subjects of educational space. Higher quality content appears. It is not a simple sum of knowledge, but a set of integrable parts [11].

We consider an example of the motion of integrating subjects to a certain integrity - a common educational space - by the example of the CIS countries. Can we speak in modern conditions about preserving the unity of the CIS, about development of a common educational space of the Commonwealth countries? What is the condition of its integrity and unity?

As evidenced by European scientists and analysts (Ewald Böhlke, Horst Grabert, Fran Uiger Andreas Vera et al.), the interrelation and interdependence of the CIS countries are obvious, and, in their opinion, the existing between these countries the social, economic, historical, cultural, educational interrelation will eventually ensure the restoration of political and economic unity of the post-soviet space [12]. Scientists believe that today we can speak about the existence on the former Soviet Union the necessary general prerequisites for the rapprochement, which at one time allocated B. Hettne the so-called "cohesion objective factors". Consolidation of the former Soviet Union today is objective and inevitable process, which is based on the strength of past relationships. Consolidation of the former republics of the Soviet Union today is an objective and inevitable process, basing upon the profound past relations: social sphere is represented by ethnic composition, language, culture, history and the awareness of the common history, economic sphere - by trade, investments, finance, political sphere - by the type of the regime and ideology, organization - by the regional institutions [13].

A factor, contributing to the consolidation of the CIS countries, is education. In the opinion of Russian and foreign researchers, the unified system of education, formerly common for all the CIS countries, stipulates the existence of the integral educational space in CIS. Today the educational space of the Commonwealth countries is developing in line with global trends of globalization and integration. Scientists assume the process of disintegration of the unified educational space of the CIS to be inevitable and perceive it as a natural cultural and historic process in which it is possible to discuss certain stages, moving forces, mechanisms of formationa and development (V.S. Lazarev, M.M Potashnik). Experts assume that_independent educational space, which have arisen as a result of government reforms, lost their former unity of education as a structure, but it retained its integrity [14].

For our research it is important to the explanation and understanding of the essence of the processes that are 
now characteristic of the educational space of the CIS countries; whether it is possible to claim that it acts as a general, unified, holistic.

To answer these questions, it is important to consider the very concepts of "one", "integrity", "common" space in relation to the CIS countries.

The unity of space is achieved by forming a unified form, content and methods of education, which are provided by common to all countries normative documents on the organization of education (drafts and recommendations), a single certificate, certificates, diplomas of educational institutions, common historical basis is important for any_national education systems. Unity is also determined by the active cooperation between the subjects of educational space. Educational structures can succeed in the successful resolution of scientific, educational and social problems, which are important for the countries that are the subjects of a common educational space, consolidating their efforts.

The concept of unified space includes a certain territory and the processes taking place there as the way of interaction with each other, integrated, independent, diverse elements of the space. The common space is a field where there is a combination of elements: norms, rules, attitudes, values, meanings, etc.

CIS space is holistic because it acts as part of a holistic metaspace (the Eurasian, the world). It, in turn, is a system of a real time voluntary educational (contractual) relationships that develop and deepen the interaction, mutual complement and ensure purposeful interaction between educational structures exist in the sustainable territorial division.

The integrity of the space characterized by internal contradictions, which is the source of its own development. This is objectively determined by contradictions_within the national educational systems of different countries and between themselves.

Integration and further development of the Commonwealth of interaction processes can be effective in several mandatory conditions. Informatization is essential.

A fundamental change occurred in education policy of the post-Soviet states in the past few decades, caused by the social and cultural transformations taking place in CIS countries. Strengthening of the national orientation in education and culture of the CIS has led to changes in the dialogue of cultures between countries. Educational policy of the CIS countries is based on dialogue and interaction of state bodies and public organizations, educational institutions of all levels: interstate, regional, national.

Modern educational policy is seen as a set of strategies (targets) that define today the functioning and development of the education systems of countries in the framework of agreements existing in the CIS model and national legislation. National-regional dimension of the educational policy of the CIS countries is determined by the components of the content of education, powers and functions of the education authorities, which express the national and regional peculiarities of education and culture, language, way of life, history that have found expression in the needs and interests of the subjects of the educational space of the CIS.

Today, the overall educational policy of the CIS countries is economic, organizational, pedagogical and other conditions for the effective functioning of the educational space of the CIS, the formation of regional systems and national levels, taking into account the dynamics of development of the regions and the CIS member states, social and cultural specificity of the territory, the preservation and development of the CIS as a competitive system of social partnership.

Of particular importance for the unity and integrity of the educational space has informatization as both informational and educational component (or subspace), under which in the broadest sense it is understand the development of the information society. The basis of the information space is the creation and use of information resources. Scientists around the world celebrate the importance of information for the development of the global world, strengthening the linkages and interdependencies, the formation of unified spaces: sociocultural, economic, political, educational. Interaction and relationships are the basis for the formation of common spaces in the world. At the present stage of civilization development scientists note not only quantitative expansion of informatization of spheres, but also its qualitative changes associated with the emergence of other forms of communication. An important feature of the emerging information environment is that there are more channels of information and opportunities for interaction between people and cultures. This is due to the changing the role of information, which, according to the famous American futurist E. Toffler, becomes more valuable than ever, and a new civilization will rebuild the system of education and research, and in addition, reorganizes the media [15,76 ]. An important feature of the information society is the fact that it is not just a lot of information, but there is a new type of information knowledge. "Axial principle" of society, according to this concept, it is theoretical knowledge. Society is built on knowledge (D. Bell, N. Stehr, Giddens and others) $[16,17,18]$.

Informatization today is associated with expectation of the new positive possibilities in the development of the individual and society and in shaping the world of unified spaces (educational and other), the general union for the countries. Assessing the importance of information for the development of modern society, a unified world educational space, a well-known sociologist M.Kastels says that communication is becoming more and more critical in shaping society. Computers have revolutionized the communication process, and through it the culture as a whole, creating opportunities for combining [19, 341].

The concept of "informatization" can be viewed from the point of allocation of a set of measures that can be made to ensure the fullest possible use of a fair, comprehensive and advanced knowledge in all areas of human activity. Let us consider informatization of education systems of states - participants of the CIS from this point. It will include work on the development of the Internet, distance learning, creation and implementation 
of information and communication technologies to improve education at all levels and educational systems and institutions of governance. Cooperation for the realization of the goals of education, educational community takes place at several levels: local (between institutions); regional (as the interaction of regional systems of education via the Internet); and international (including regional educational systems into the information system of the CIS countries).

Informatization of the CIS countries is a factor that contributes to the integrity of the common educational space, it is carried out through the development and formation of primarily Internet - education. This activity takes place on the basis adopted by all the CIS memberstates of the Concept of formation of single (general) educational space of the CIS (the main program of cooperation of the CIS states in the field of education). Using Internet technology, the Commonwealth of distance learning are developing a real opportunity to create a common educational space on the basis of the distributed on-line educational community (community groups, segmented by professional interests, or other characteristics, such as the teaching of economics) of educational institutions of Russia and CIS countries, their integration into the common educational space of the Internet (national and international). Interstate network of Open and Distance Education (MS ODL), bringing together educational institutions of the CIS countries, as well as their separate subdivisions (branches and representative offices) is the basis for cooperation in the field of informatization of educational systems in the CIS, taking into account the main landmark - the formation of united (general) holistic education space [20].

An important component of the formation of a single educational space is the responsibility of the CIS states for the development of national segments of the network and their integration into a single system. All States are developing their national segment, expanding the network of educational institutions and their structural units, which are actively using the services of distance education, using educational technologies; increase the coherence of communication networks and expand their territories network of branches and representative offices of leading educational institutions of other states. Especially noteworthy versatility of branches and representative offices, in particular, the possibility of their use for distance training, retraining and advanced training of teaching staff, particularly national, and their gradual transformation into resource centers of sharing countries - participants of the CIS. We have identified and marked a strategic perspective on the transformation of open and distance education institutions operating in such networks, the creation of conditions for coordination and scientific-methodical, informationsharing centers and interstate public universities, as well as the other jointly organized the educational institutions. The distinguishing feature that characterizes create shared documents is the fact that they are based on the mutual interest of countries - participants of the CIS to address the problems of development of education based on advanced information and communication technologies, training of subjects of educational activity residing on their territories of their choice on their chosen program language and the integration of education systems of these countries in the global educational process.

Today we celebrate the opportunity to fix the formation and development of a common educational space of the CIS countries, its integrity on the basis of differing national educational spaces on the basis of uniform regulatory documents, adopted by all countries of the Commonwealth, national law "On Education", the CIS member states, model laws, the positions of scientists and experience of real interaction of subjects of educational space.

More than twenty years of independent development of the CIS countries allows to accumulate valuable experience, which, being acquired by one state, can be used efficiently by others. Today we see that due to the joint efforts the Commonwealth becomes a powerful regional economic center, and its potential is one of the most promising interstate formations.

\section{References}

1. Yu.V. Shishkov, Integratsionnyie protsessyi na poroge XXI v., Pochemu ne integriruyutsya stranyi SNG, (III tyisyacheletie, M. (2001) [In Rus]

2. On-line Dictionary. Available online: URL http://www.m-w.com/dictionary/integration (accessed on: 22.02.2015)

3. J. Sartori, Polis, 5, 67-77 (2003) [In Rus]

4. J.C. Piano, R.E.Riggs, H.S.Robin, The Dictionary of Political Analysis (ABC - Clio, USA, 2000).

5. A. Wendt, International organization, 46, 2, 391-425 (1992) [In Rus]

6. A. Bendedict, Imagined Communities (Verso, New York, 2006)

7. A. Hurrell, Review of International Studies, 21, 331358 (1995)

8. A. Wendt, International organization, 46, 2, 391-425 (1992)

9. V.A. Myasnikov, Obrazovanie v stranah $S N G v$ menyayuschemsya mire (Moskovskiy psihologosotsialnyiy institut, Moscow, 2010) [In Rus]

10. I.A. Tagunova, Vestnik MGU, 4, 3-16 (2009) [In Rus]

11. V.A. Myasnikov, Otechestvennaya i zarubezhnaya pedagogika, 2 (5), 23-31 (2012) [In Rus]

12. H. Grabert, Wehe, wenn $d u$ anders bist. Ein politischer Lebensweg für Deutschland (Stekovics, Dößel, 2003)

13. Megatrends. World Order Evolution in the 21st Century (Aspekt Press, Moscow, 2013) [In Rus]

14. V.S. Lazarev, M.M. Potashnik, Kak razrabotat programmu razvitiya shkolyi: metod. rekomendatsii, (Novaya shkola, Moscow, 1993) [In Rus]

15. E. Toffler, Tretya volna (Moscow, 1999) [In Rus]

16. E. Giddens, Uskolzayuschiy mir. Kak globalizatsiya menyaet nashu zhizn (Ves mir, Moscow, 2004) [In Rus] 
17. D. Bell, and V. Inozemtsev, Epoha razobschennosti (Tsentr issledovaniy postindustr-go obschestva, Moscow, 2007) [In Rus]

18. R. Grundmann, N. Shter, Vlast nauchnogo znaniya (Moscow, 2015) [In Rus]

19 M. Kastels, Ekonomika, obschestvo i kultura, 353 (2000) [In Rus]

20. Reintegratsiya $i$ integratsiya bratskih narodov postsovetskih respublik - istoricheskaya neobhodimost sovremennosti, (Kanon, Moscow, 2013) [In Rus] 